\title{
Studies of meteorological elements and climate change in the Uruçuí river
}

\section{basin/Brazil}

\section{Estudos dos elementos meteorológicos e mudança de clima na bacia hidrográfica do rio}

\section{Uruçuí/Brasil}

Estudios de elementos meteorológicos y cambio climático en la cuenca del río Uruçuí / Brasil

Manoel Vieira de França

ORCID: https://orcid.org/0000-0003-4973-9327

Universidade Federal Rural de Pernambuco, Brasil

E-mail: manoelvieiraufrpe@gmail.com

Wagner Rodolfo de Araújo

ORCID: https://orcid.org/0000-0001-7203-0338

Universidade Estácio de Sá, Brasil

E-mail: wagneraraujops@gmail.com

Victor Casimiro Piscoya

ORCID: https://orcid.org/0000-0003-1875-9771

Universidade Federal Rural de Pernambuco, Brasil

E-mail: victor.piscoya @ufrpe.br

Guilherme Rocha Moreira

ORCID: https://orcid.org/0000-0001-6344-1151

Universidade Federal Rural de Pernambuco, Brasil

E-mail: guirocham@gmail.com

Maria Lindomárcia Leonardo Costa

ORCID: https://orcid.org/0000-0003-1345-0169 Universidade Federal da Paraíba, Brasil

E-mail: lindomarcia@cca.ufpb.br

Renisson Neponuceno de Araújo Filho

ORCID: https://orcid.org/0000-0002-9747-1276

Universidade Federal do Tocantins, Brasil

E-mail: renisson@uft.edu.br

Thaísa Oliveira Folha Piscoya

ORCID: https://orcid.org/0000-0002-8419-1566 Superintendência do Desenvolvimento do Nordeste, Brasil E-mail: thaisafolha@gmail.com

Cícero Carlos Ramos de Brito

ORCID: https://orcid.org/0000-0002-3699-5156 Instituto Federal de Educação, Ciência e Tecnologia de Pernambuco, Brasil

E-mail: cicerocarlosbrito@yahoo.com.br 
Frank Sinatra Gomes da Silva

ORCID: http://orcid.org/0000-0002-3481-3099 Universidade Federal Rural de Pernambuco, Brasil E-mail: franksinatrags@gamil.com

Luciano Marcelo Fallé Saboya

ORCID: http://orcid.org/0000-0002-7586-6867

Universidade Federal de Campina Grande, Brasil E-mail: 1saboya@hotmail.com

Moacyr Cunha Filho

ORCID: https://orcid.org/0000-0002-3466-8143 Universidade Federal Rural de Pernambuco, Brasil E-mail: moacyr.cunhafo@ufrpe.br

\begin{abstract}
The objective is to show the variability of meteorological elements in the hydrographic basin area of the hydrographic basin of the Uruçuí Preto River-PI/Brazil, aiming to contribute to sustainable development in the productive areas of agriculture, laser, and hydrology. The meteorological elements studied are air temperature and relative humidity and their fluctuations, thermal amplitude, wind (intensity and direction), total insolation, cloud cover, evaporation, evapotranspiration, and rainfall. The data were from the 1960-1990 series, acquired by the Superintendency of the Development of the Northeast and by the Technical Assistance and Rural Extension Company of Piauí. The maximum annual temperature is $32.1^{\circ} \mathrm{C}$, its minimum $20.0^{\circ} \mathrm{C}$, with an average annual temperature of $26.1^{\circ} \mathrm{C}$. A climatic classification was used according to the KÖPPEN systems, where two climatic types are distinguished in the Uruçuí Preto/PI river basin, the Aw, tropical hot and humid, with rain in summer and dry in winter; Bsh, warm semiarid, with summer rains and dry winter. The variation of the thermal amplitude is from 11.9 to $14.9^{\circ} \mathrm{C}$. The average relative humidity of the air was 47 to $79 \%$; the average annual precipitation was $937.7 \mathrm{~mm}$; it was observed that the annual march of relative humidity follows the annual distribution of precipitation because the precipitation was the feeding process from natural sources of water vapor and moisture. Total Sunstroke in the BHRUP area ranges from 2520 to 2750 hours. It is concluded that the maximum annual temperatures increased during the period, which can cause several socioeconomic problems, and human health.
\end{abstract}

Keywords: Climate variability; Climate change; Water balance; Monthly and annual fluctuations.

\title{
Resumo
}

O objetivo é mostrar a variabilidade dos elementos meteorológicos na área da bacia hidrográfica do rio Uruçuí PretoPI/Brasil, visando uma contribuição ao desenvolvimento sustentável nas áreas produtivas da agropecuária, laser e hidrologia. Os elementos meteorológicos estudados são: temperatura e umidade relativa do ar e suas flutuações, amplitude térmica, vento (intensidade e direção), insolação total, cobertura de nuvens, evaporação, evapotranspiração e precipitação pluvial. Os dados foram da série de 1960-1990, adquiridos pela Superintendência do Desenvolvimento do Nordeste e pela Empresa de Assistência Técnica e Extensão Rural do Piauí. A temperatura máxima anual é de $32,1^{\circ} \mathrm{C}$, sua mínima de $20,0^{\circ} \mathrm{C}$, com temperatura média anual de $26,1^{\circ} \mathrm{C}$. Utilizou-se classificação climática de acordo com os sistemas de KÖPPEN, onde se distinguem dois tipos climáticos na bacia do rio Uruçuí Preto/PI, o Aw, tropical quente e úmido, com chuvas no verão e seca no inverno; Bsh, semiárido quente, com chuvas de verão e inverno seco. A variação da amplitude térmica é de 11,9 a $14,9^{\circ} \mathrm{C}$. A umidade relativa do ar média foi 47 a $79 \%$, a precipitação média anual foi de $937,7 \mathrm{~mm}$, observou-se que a marcha anual de umidade relativa do ar acompanha a distribuição anual da precipitação, porque a precipitação foi o processo de alimentação das fontes naturais de vapor da água e umidade. A Insolação total na área da BHRUP oscila entre 2520 a 2750 horas. Conclui-se que as temperaturas máximas anuais aumentaram durante o período podendo acarretar vários problemas socioeconômicos, bem como, para a saúde humana.

Palavras-chave: Variabilidade climática; Mudanças climáticas; Balanço hídrico; Oscilações mensais e anuais.

\section{Resumen}

El objetivo es mostrar la variabilidad de los elementos meteorológicos en el área de la cuenca hidrográfica del río Uruçuí Preto-PI / Brasil, apuntando a una contribución al desarrollo sostenible en las áreas productivas de agricultura, láser e hidrología. Los elementos meteorológicos estudiados son: temperatura del aire y humedad relativa y sus fluctuaciones, amplitud térmica, viento (intensidad y dirección), insolación total, nubosidad, evaporación, evapotranspiración y lluvia. Los datos fueron de la serie 1960-1990, adquiridos por la Superintendencia de Desarrollo del Nordeste y por la Empresa de Asistencia Técnica y Extensión Rural de Piauí. La temperatura máxima anual es de $32,1^{\circ} \mathrm{C}$, su mínima de $20,0^{\circ} \mathrm{C}$, con una temperatura media anual de $26,1^{\circ} \mathrm{C}$. Se utilizó una clasificación climática según los sistemas KÖPPEN, donde se distinguen dos tipos climáticos en la cuenca del río Uruçuí Preto / PI, el Aw, tropical cálido y húmedo, con lluvia en verano y seco en invierno; Bsh, semiárido cálido, con lluvias de verano e invierno seco. La variación de la amplitud térmica es de 11,9 a $14,9^{\circ} \mathrm{C}$. La humedad relativa promedio del aire fue de 47 a 79\%, la precipitación promedio anual fue de $937.7 \mathrm{~mm}$, se observó que la marcha anual de la humedad relativa sigue la distribución anual de la precipitación, debido a que la precipitación fue el proceso de alimentación de fuentes naturales de agua. vapor y humedad. La insolación total en el área de BHRUP varía de 2520 a 2750 horas. Se 
concluye que las temperaturas máximas anuales aumentaron durante el período, lo que puede ocasionar diversos problemas socioeconómicos, así como para la salud humana.

Palabras clave: Variabilidad climática; Cambios climáticos; Equilibrio hídrico; Fluctuaciones mensuales y anuales.

\section{Introduction}

The conditions of the climatic and hydrological elements of a given region are the main parameters in the estimation of water availability in that territory and/or region. Thus, in hydro climatological studies, these are basic assumptions that will guide the development of work in defining the planning and management model of water resources to be implemented. In this way, the compatibility between water availability and demand can only be done when the climatic parameters, especially precipitation, evaporation and evapotranspiration, and hydrological parameters, such as the movement and quantification of surface and groundwater in time and space, are duly considered (Eguchi \& Albino, 2021).

The climatic variety also influences the environment, acting as interactions between biotic and abiotic components. The climate of any region, situated in the most diverse latitudes of the globe, does not present the same characteristics every year (Soriano, 1997; Sousa Silva \& Suertegaray, 2018).). In a climate region of contrasting neighboring areas on one rainy side on the other semi-arid, such as the Northeast of Brazil (NEB) and especially the State of Piauí, the monitoring of precipitation, especially during the rainy season, is essential for decision making that will benefit the population. Good rainfall monitoring is an indispensable tool in mitigating droughts, and waterlogging (Paula, Brito \& Braga, 2010). Among the elements of climate in tropical areas, rainfall is the one that most influences agricultural productivity (Ortolani \& Camargo, 1987; Diaz, Pereira \& Soares, 2017).), especially in the semi-arid region, where the rainfall regime is characterized by events of short duration and high intensity (Santana et al., 2007). as a result, rainfall (precipitation) seasonality concentrates almost all its volume during the five to six months in the rainy season (Silva, 2004).

Spatial and temporal variation are characteristics of weather and climate. The temporal variation is a characteristic that should be studied with greater particularity and on different chronological scales. Because these studies will allow the knowledge of the climate in the past, present, and even make prognoses and diagnoses for future climatic situations from the mathematical models used (Fernando, 2008).

Several studies have been prepared on climate variability and its characteristics, so it is still far from reaching a consensus, especially concerning the local influence on global trends. However, studies of local climate variability, especially on temperature, relative humidity, and precipitation, are essential to understand the impacts of these variations on the population in general. Suppose the fluctuations are significant at the local level. In that case, these changes can cause socioeconomic impacts, on agricultural and livestock production, environmental impacts, changes in ecosystems, and social impacts, proliferation of disease vectors (Maluf \& Rosa., 2011).

Precipitation is fundamental for climate characterization (Marinho \& Rivera, 2021).). Its monitoring is important for managing and maintaining water resources because it provides data that contribute to public planning and studies that seek the sustainable use of water. Rainfall data, for example, are essential for studies like those of D'Almeida et al. (2006), Costa et al., (2007), Sampaio et al. (2007), and Coe, Costa \& Soares-Filho (2009), who concluded that the deforestation of the Amazon Forest is directly the imbalance in the environment, especially in the hydrological cycle, wherein simulations showed a significant decrease in evapotranspiration and precipitation.

According to Silva et al. (2013), the State of Piauí has differentiated climatic conditions, with oscillation in rainfall rates whose origin is quite individualized, also presenting relatively variable average annual temperatures. Rainfall presents great spatial and temporal variability (Costa et al., 1998), showing two rainy regimes: in the south of the State, it rains from November to March; in the center and north, the rainy season begins in December, extending until May. Rainfall rates vary between 700 and $1,300 \mathrm{~mm}$ in the southern region, between 500 and 1,450 $\mathrm{mm}$ in the central region, and between 800 and 
$1,680 \mathrm{~mm}$ in the north of the State. In the North region, rainfall indices have a more regular distribution than in the Central and South areas, evidencing the physiographic aspects, relief, fauna, flora, and distance from the sea. Due to the large variation in rainfall over the years, it can be observed that the phenomena of macro, medium, and micro scales are of great importance for the rainfall regimes in the State of Piauí, which follow the chronological time of their activities and duration.

Medeiros et al. (2013) refers to variability as one of the best-known elements of climate dynamics, and the impact produced by this phenomenon, even within the expected range, can have significant reflections on human activities. We used data on maximum air temperature and relative humidity and monthly and annual rainfall totals from 1960 to 1990 . As a result of this work, it can be affirmed that the maximum annual temperatures increased during the analyzed period, which can cause several socioeconomic problems and problems for human health. From the data, it was also verified that the relative humidity of the air is decreasing throughout the series studied, which may be related to the increase in temperature and, consequently, to greater water evaporation. Regarding the total annual rainfall, it was noted that the values are gradually increasing, and this increase may be related to the increase in temperature, which causes greater evaporation and consequently more significant precipitation.

According to Marengo \& Camargo (2007), the thermal amplitude for southern Brazil showed sharp negative trends in the period 1960-2002, indicating that the minimum temperatures were more intense than the maximum temperatures, especially in summer. For Rusticucci \& Barrucand (2004), negative trends in diurnal thermal amplitude are due to positive variations in minimum temperature trends. According to the analyses by Marengo \& Camargo (2007), the observed warming seems to be more intense in winter than in summer, which is probably related to the increase in the number of warm days in winter (Campos, 2010).

Air temperature expresses in a simple way the energy contained in the medium. During a day, the energy available in the environment oscillates between two extreme values, between the minimum and maximum temperature. As this energy goes from one extreme to the other, it continuously stimulates vital physiological processes in living beings such as the development and growth of plant species, such as transpiration, respiration, germination, growth, flowering, and fruiting. At each stage of plant development, there are suitable temperature ranges for its perfect development (Costa, Costa Filho \& Brandão, 2011). Moreover, the daily temperature cycle predominates in thermal comfort and the adequacy of human and animal beings in certain places. Rodrigues et al. (2016) showed that the minimum temperature variability for the municipality of Lavras / MG has been changing minimum values.

Medeiros et al. (2014) analyzed the predominant monthly wind directions over the Uruçuí Preto river basin. The predominant wind direction was described from the frequency of occurrence in a given direction, the methodology adopted from Galvani et al. (1999). The predominant wind directions for the basin and the referred predominant contributions for the rainy and dry periods were represented. Medeiros (2010) clarified that the possibilities of mobile dune barrages should be worked on in the largest entrances of the predominance of winds and their intensities. A counter was performed to calculate the predominant wind input frequency for the studied area. The predominant directions with the highest input frequencies were: northeast-southeast with 19 times, east-southeast with 13 times, and northeast with 5 times around the basin.

The objective was to demonstrate that the meteorological elements studied such as maximum air temperature, minimum air temperature, average air temperature, and their maximum and minimum fluctuations, temperature range, relative air humidity, wind (intensity and direction), insolation total, cloud cover, evaporation, evapotranspiration, and rainfall have their contributions to climate variability and its oscillations targeting climate change in the area of the hydrographic basin of the Uruçuí Preto-PI (BHRUP)/Brazil river. As well as analyzing the municipal rainfall variability between the different rainfall regimes for the state of Piauí (North, Central and South regions), it was proven that they have common areas of rainfall 
occurrences with their respective provocative and inhibitory systems. Finally, we sought to analyze the climate variability of relative air humidity and maximum air temperature in the Uruçuí Preto River basin - PI, focusing on such variations as a means to understand future changes. Data on maximum air temperature and relative humidity and monthly and annual rainfall totals from 1960 to 1990 were used.

\section{Methodology}

The area of interest of the study has a reduced and spatially poorly distributed network of meteorological stations, which hinders a good characterization of the climatic conditions. Thus, we used interpolated data, estimated and generated by straight lines of multiple linear regressions, through the software estima_T (Cavalcanti \& Silva, 1994; Cavalcanti, Silva \& De Souza, 2006). To analyze the inter-municipal climatic behavior of the Uruçuí Preto river basin, precipitation data acquired through the Superintendence for the Development of the Northeast - SUDENE, and the Company for Technical Assistance and Rural Extension of the State of Piauí - EMATER/PI, for the period from 1960 to 1990 were used, comprising 49 rainfall posts located in the study area.

The region is drained by the Uruçuí Preto River and its tributaries Ribeirão dos Paulos, Castros, Colheres and Morro da Água, and by the Estiva and Corrente creeks, both perennial. The Uruçuí Preto river basin is preponderantly located in the sedimentary basin of the Parnaíba river, constituting one of the main tributaries on the right margin. It has a total area of approximately 15,777 km2, representing 5\% of the territory of Piauí. It covers part of the southwest region, projecting from south to north in a spear (Comdepi, 2002).

The Uruçuí Preto river basin comprises 25 municipalities and 24 farms containing rainfall data with a 30-year series (1960-1990 period). The maximum annual temperature is $32.1^{\circ} \mathrm{C}$, the minimum annual temperature is $20.0^{\circ} \mathrm{C}$, and the average annual temperature is $26.1^{\circ} \mathrm{C}$. We used the Climatic Classification according to the KÖPPEN systems, where two climatic types are distinguished in the basin of the Uruçui Preto river - PI, the Aw, tropical hot and humid, with summer rains and dry winter; is the Bsh, semi-arid hot, with summer rains and dry winter (Medeiros, 2013; Medeiros, de Holanda \& Alexandre, 2018; Medeiros, Cavalcanti, \& Medeiros Duarte, 2020).

The precipitation regime that comprises the study area begins with the pre-season rains, starting in the second half of October. The characterization of the rainy season begins in the first days of November and extends until March, with December, January, and February as the rainiest quarters.

The predominant rainfall factors for Uruçuí the Preto river basin are the formation of instability lines carried by the Southeast-Northeast trade winds, heat exchanges, traces of cold fronts when their most active penetrations convective cluster formations, orography, cyclonic vortex formation contributions, conveyor belt, orography, and local effects, are factors that increase the transport of water vapor and moisture and consequently the cloud cover. 
Figure 1. Location of the Uruçuí Preto river basin - PI/Brazil.

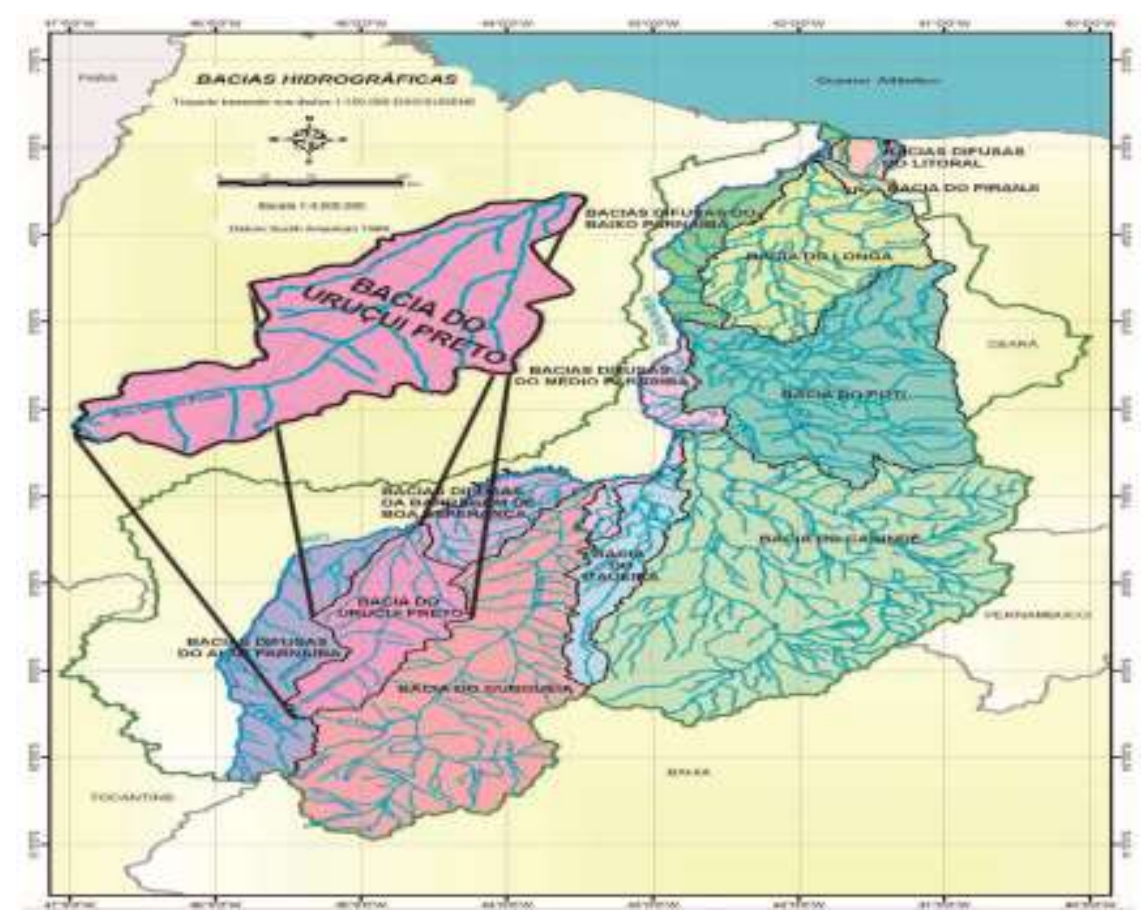

Source: Adapted from Medeiros (2016).

Usually, the rains have moderate intensity, fregular weather and around seven to eight hours of discontinuous daily rainfall, followed by irregularity due to the failures of the acting meteorological systems. It is emphasized that summer periods, occurrences of several consecutive days without rain during the rainy season, in the four months (December, January, February, March) are expected. Its magnitude varies depending on the season and the meteorological factors that are off. It has been recorded occurrences with summers longer than nineteen (19) days in the time interval within the four months. Medeiros (2013).

\section{Results and Discussion}

In this section, the results are presented using figures from the meteorological elements in the area of the hydrographic basin of the Uruçuí Preto-PI - BHRUP/Brazil river from the 1960-1990 series, acquired by the Superintendence for the Development of the Northeast - SUDENE, and by the Piauí Technical Assistance and Rural Extension Company EMATERPI.

In Figure 2 (a, b , c, d, e) represents the temperature range (a) of the coldest month; (b) hottest month; (c) coldest four months; (d) hottest four months; (e) and annual, for the Uruçuí Preto river basin area - PI.

In Figure 2a shows the temperature range of the coldest month (January) for the area of the BHRUP; it is observed that the west and the extreme southwest predominate the area of the lowest ranges, the range of average ranges predominates throughout the area (north, central and south) with its fluctuation ranging from 9.58 to $9.78{ }^{\circ} \mathrm{C}$, it was also observed a small area of temperature range greater than $9.78{ }^{\circ} \mathrm{C}$ in the eastern sector of the study area.

In Figure $2 \mathrm{~b}$ represents the temperature range of the hottest month (September) for the area of the BHRUP; it is observed a range of temperature range in the extreme south of the study area greater than $15^{\circ} \mathrm{C}$, a area in the southeast and southwest sectors as amplitude ranging between 14.7 to $15.2^{\circ} \mathrm{C}$ and part of the southern region, part of the central region with temperature range ranging between 14.5 to $15.2{ }^{\circ} \mathrm{C}$, the predominant temperature range in the central part and throughout the 
northern area is $15.3{ }^{\circ} \mathrm{C}$. In Figure 2c shows the thermal behavior of the coldest four months (December to March), which follows the characteristics of Figure 2a.

In Figure $2 \mathrm{~d}$ shows the behavior of the variability of the temperature range for the warmest four months (June to September), it is observed a small area of maximum amplitude in the extreme southwest and an area of minimum amplitude in the north and northeast and a small area near the city of Gilbués. In the south, central and north regions, there is a variability of the thermal amplitude oscillating between 14.3 and $14.7^{\circ} \mathrm{C}$.

In Figure 2e an increase is observed in the north-south direction; it is highlighted that the areas of lower amplitudes are located in the north and northeast and a small range in the southwest, in the central region, south, and part of the south of the northern region it is seen the variability of the temperature range fluctuating between 12 and $12.3{ }^{\circ} \mathrm{C}$ it is noted that the range of southeast to the southwest is characterized by the largest annual temperature ranges.

Figure 2. Temperature range $\left({ }^{\circ} \mathrm{C}\right)$ : (a) cold month; (b) warmest month; (c) coldest four months (d) warmest four months; (e) and annual.

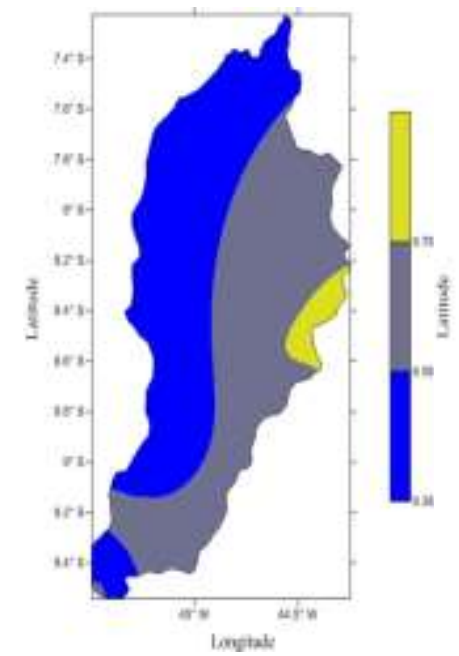

(a)

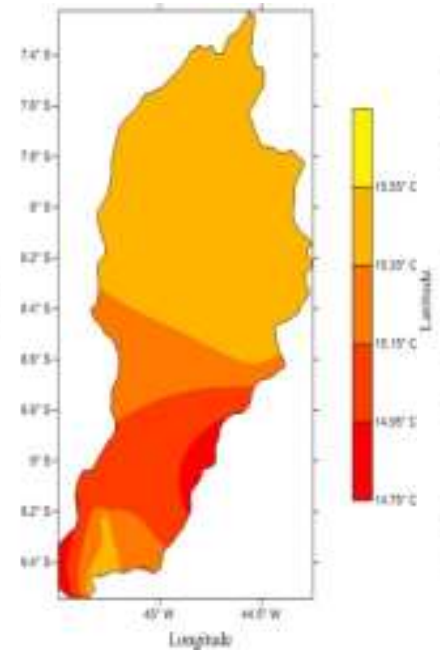

(b)

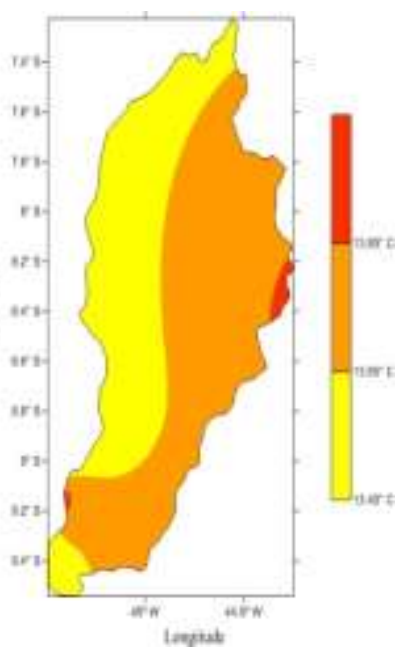

(c)

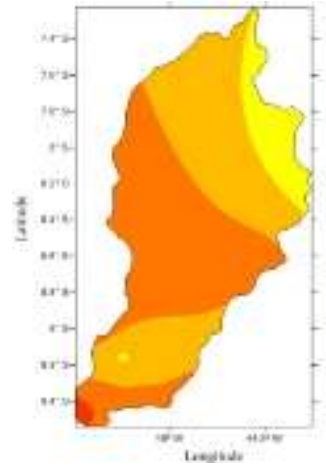

(d)
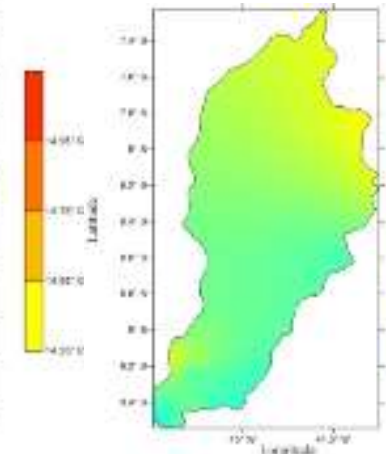

(e)

Source: Adapted from Medeiros (2016).

In Figure 3a a gradual increase in the south-north direction is observed, noticing that the greatest fluctuations of the maximum and minimum temperatures occur north of the central region and in the entire area of the north and northeast region.

In Figure $3 \mathrm{~b}$ shows the persistence of the gradual increase of the maximum temperature in the direction from south to north, a small area in the southwestern sector with maximum temperature, it is observed that in the southern region occurs reductions of maximum temperatures and in other areas predominate high temperatures of maximums. 
In Figure 3c, we have the variability of maximum temperature for the coldest four months (December to March), in which we highlight an increase in the south-north direction with its most intense oscillations in the central and northern sector and a small area in the southwestern sector, the southern and western sector of the central sector record the lowest values of the maximum temperature of the four months.

Figure $3 \mathrm{~d}$ represents the oscillations of maximum temperature for the warmest four months (June to September) in the area of the BHRUP; it is observed a small area of maximum temperature in the southwestern sector and a gradual increase of this parameter in the south-north direction, with its highest value centered in the north and part of the central region.

The annual variability of the maximum temperature occurs with greater intensities in isolated areas of the southwestern and northeastern sectors and in a small area of the central region, according to Figure 3e. The annual variability occurs in the range of 31.5 to $33.3^{\circ} \mathrm{C}$ throughout the basin under study.

Figure 3. Maximum temperature $\left({ }^{\circ} \mathrm{C}\right)$ : (a) of the minimum; (b) of the maximum; (c) coldest four months (d) warmest four months; (e) annual.

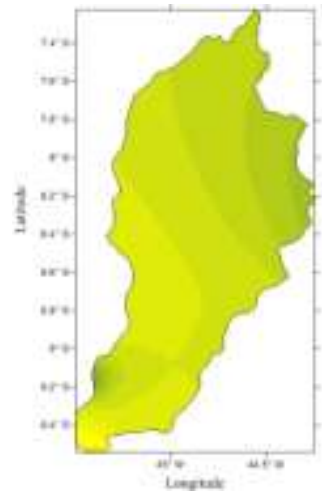

(a)

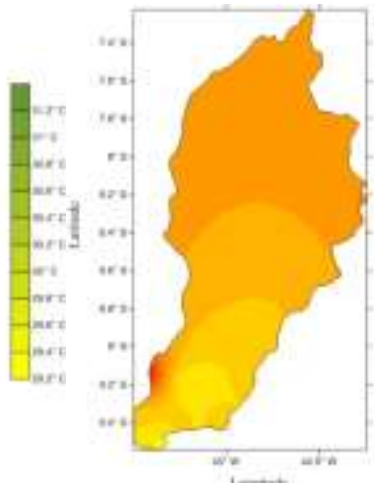

(b)
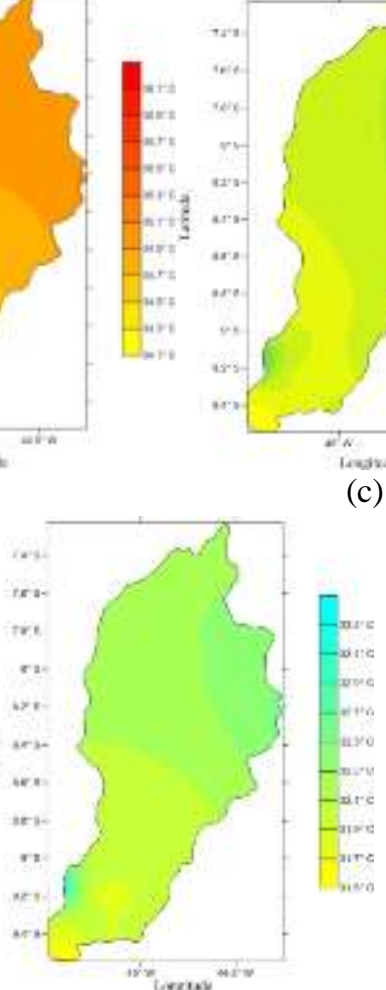

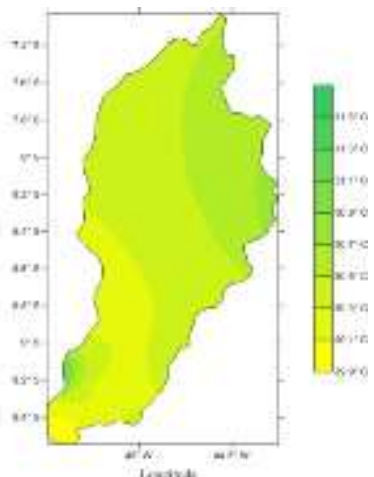

(c)

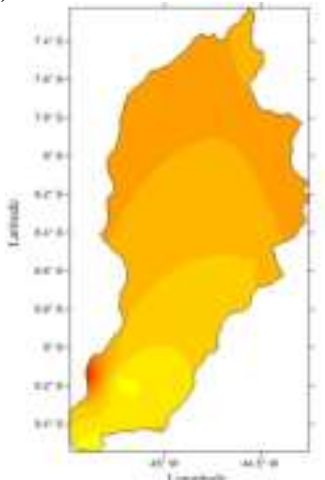

(d) (e)

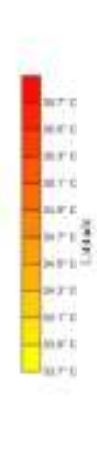

Source: Adapted from Medeiros (2016).

Figure 4 (a, b, c, d, e) represent the variability of the minimum temperature: (a) of the minimum; (b) of the maximum; (c) four-month minimum of the minimum; (d) four-month minimum of the maximum; (e) and annual, for the Uruçuí Preto river basin area - PI.

In Figure 4a, we can see the minimum temperature variability that occurs in June, where a gradual increase in the south-north direction can be seen. A small area in the southwest with $19{ }^{\circ} \mathrm{C}$ and another in the northeast with an oscillation between 18.6 and $20{ }^{\circ} \mathrm{C}$ can be highlighted.

Figure $4 \mathrm{~b}$ has the behavior of the minimum temperature of the maximum for the area of the BHRUP that occurs between August and September, realize the gradual increase in the south-north direction. The minimum temperature variations 
are more significant in the southern sectors and part of the central region; the highest minimum-maximum temperature occurs north of the central region. Throughout the northern area of the BHRUP, there are small areas in the southwestern and eastnortheastern sectors with a high minimum temperature of the maximum.

Figure $4 \mathrm{c}$ represents the four months of the occurrence of the minimum temperature of the minimum in which it highlights the areas with greater intensity located to the southwest and northeast of the figure with an oscillation ranging from 18.1 to $20.7^{\circ} \mathrm{C}$ is observed a gradual increase in that parameter in the south-north direction and a range of low minimum temperature in the southern sector.

It is observed the fluctuation of the minimum temperature for the four-month with the minimum occurrences of the maximums as shown in Figure $4 \mathrm{~d}$ where it highlights the areas of maximum elevations in the southwestern position and the northern and northeastern part of the northern region, in the other areas, occur gradual increases with oscillations ranging from 19.9 to $21.7^{\circ} \mathrm{C}$, the lowest variability of this parameter occurs in the southern region.

In Figure 4e shows us the variability of minimum annual temperature in the area of the BHRUP; the highest minimum temperatures are located in the southwest and part of the north and northeast region; in the southern region, there are two areas where is located the lowest variability of minimum temperature.

Figure 4. minimum temperature $\left({ }^{\circ} \mathrm{C}\right)$ : (a) of the minimum; (b) of the maximum; (c) four-month minimum of the minimum; (d) four-month minimum of the maximum; (e) and annual.

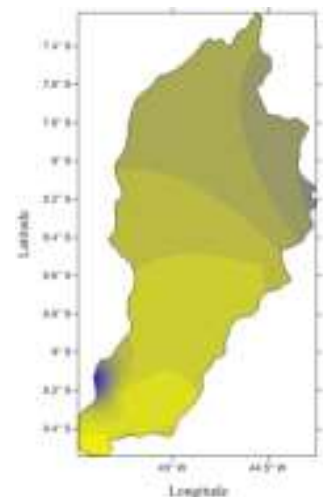

(a)

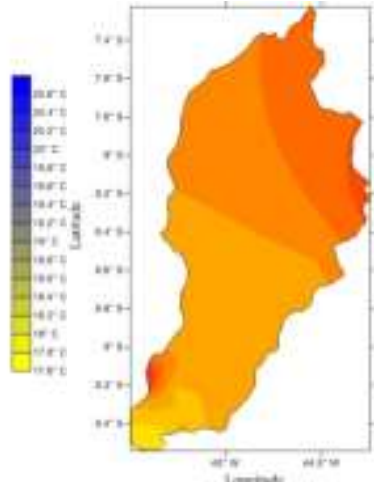

(b)

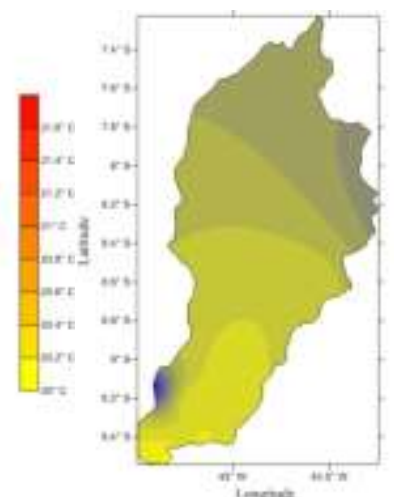

(c)

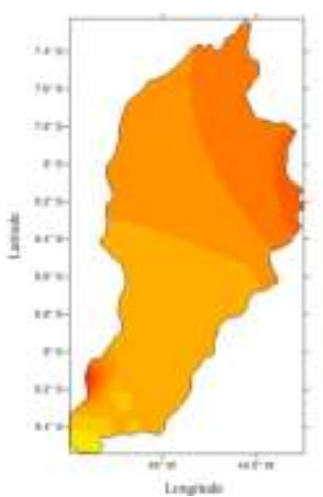

(d)

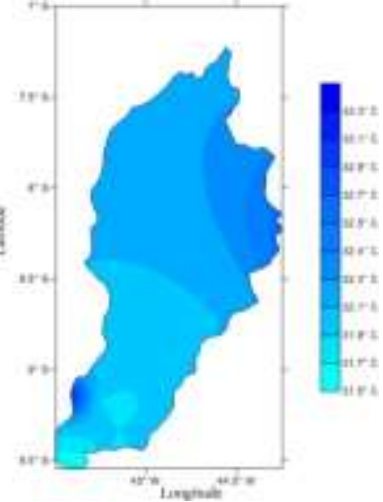

(e)

Source: Adapted from Medeiros (2016).

Figures 5 (a, b, c, d, e) represent the variability of the average temperature: (a) of the minimum; (b) of the maximum; (c) coldest four months; (d) warmest four months; (e) annual, for the Uruçuí Preto river basin area - PI.

Figure 5a shows the behavior of the average temperature that occurs in the BHRUP. Figure 5b shows the oscillations of the average maximum temperatures in which the high-temperature centers stand out in the southwestern sector, the 
northeastern sector, and the northern region, the southern and central regions have moderate average temperatures. In Figure 5c are observed the oscillations of the average temperatures for the four months of the minimum averages that occurred between the period 1960-1990. The south and north of the central region have the lowest average temperatures, followed by a gradual increase from the central sector to the north. High average temperatures are located in the northeast and southwest positions of the basin.

The variability of the average temperature of the maximum for the four months of the average maximum can be seen in Figure 5d, highlighting the areas in the southwestern and northeastern sectors as the highest and in the extreme south areas with lower values of that parameter, the central region falls between the area of moderate average temperature and the northern region as the one of high temperature.

In Figure 5e, we have the behavior of the average annual temperature, in which its oscillations occur in the range of 25 to $27^{\circ} \mathrm{C}$, in the southern regions and part of the central region are observed the lowest fluctuations of that parameter while in the north of the central region, throughout the northern region are concentrated the highest minimum temperatures.

Lima, Menezes \& De Brito (2010) analyzed the annual trends of minimum, maximum, and average compensated minimum and maximum absolute temperatures of twenty-four locations in the northern northeastern region between the states of Ceará, Rio Grande do Norte, Paraíba, and Pernambuco, where they used historical series from 1961 to 1990. The authors verified an increase in minimum and average compensated, maximum, and absolute minimum temperatures in almost the entire study area; these results are in accordance with what is observed in Figures 2, 3, 4, and 5.

Figure 5. Average temperature $\left({ }^{\circ} \mathrm{C}\right)$ : (a) of the minimum; (b) of the maximum; (c) four months of the minimum $(\mathrm{d})$ four months of the maximum; (e) and annual.

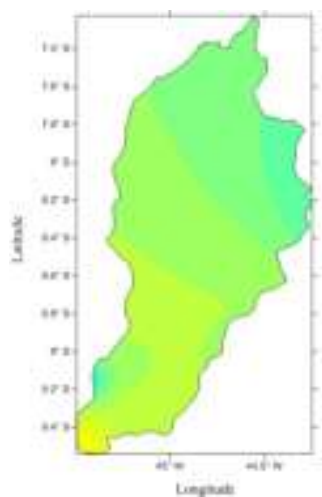

(a)

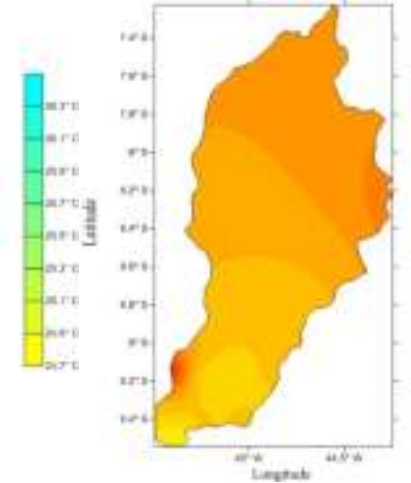

(b)

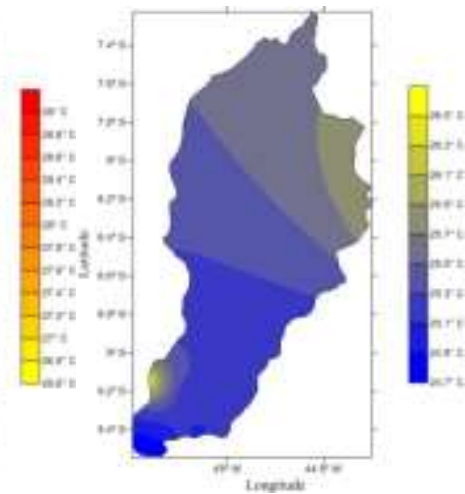

(c)

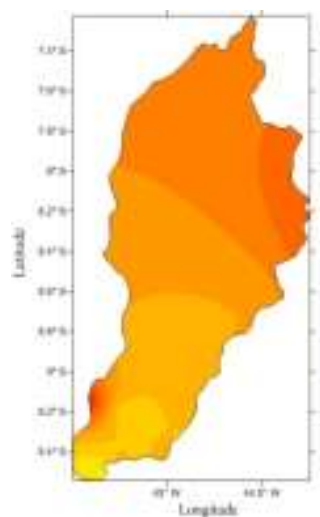

(d)

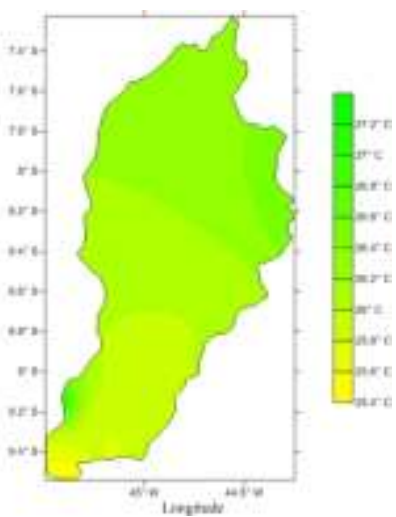

(e)

Source: Adapted from Medeiros (2016). 
In Figure 6 (a, b, c, d, e) represents the variability of evaporation (a) minimum; (b) maximum; (c) minimum four months; (d) maximum four months; (e) and annual, for the Uruçuí Preto river basin area - PI.

In Figure 6a represents the maximum evaporative power that occurs between August and September with fluctuation from 120 to $162 \mathrm{~mm}$; the northern, northeastern, southeastern, and southwestern sectors occur the highest evaporative rates, highlighting a gradual increase from south to north.

Figure $6 \mathrm{~b}$ shows the minimum evaporation that occurs in February with a monthly evaporative rate ranging from 84 to 118 $\mathrm{mm}$. It can be seen that the highest evaporative rate is located in the part of the northern area, northeast, and southeast, and the lowest evaporative rates are in the extreme south and east of the central region.

In Figure 6c shows the variability of the evaporation of the minimum four months (December to March) that has its variability between 88 to $118 \mathrm{~mm}$, highlighting the areas of lowest evaporation located in the extreme south and the eastern sector of the central region, areas with high evaporative power to the southeast, northeast and north of the BHRUP, the southern sectors of the southern region, the central area to the west and the western sector of the northern region with intermediate evaporations.

The evaporative variability of the four months of maximum evaporation can be seen in Figure $6 \mathrm{~d}$, which occurs in the range of 114 to $158 \mathrm{~mm}$ between June and September.

In Figure 6e shows an annual variability of evaporation ranging from 100 to $226 \mathrm{~mm}$ per year, the southernmost sector has the lowest evaporation rates, and there is an increase in the south-north direction, which gradually increases its evaporative power.

Figure 6. Evaporation (mm): (a) minimum; (b) maximum; (c) minimum four-month period; (d) maximum four-month period; (e) and annual.

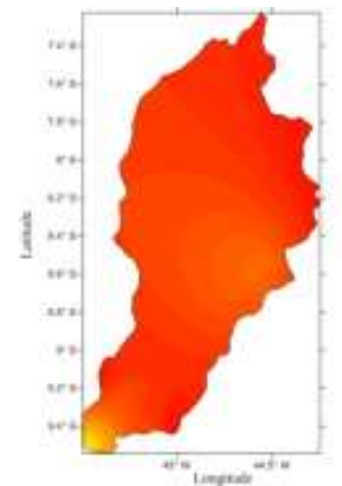

(a)

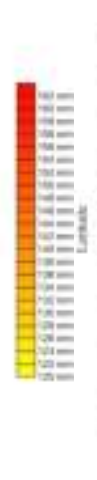

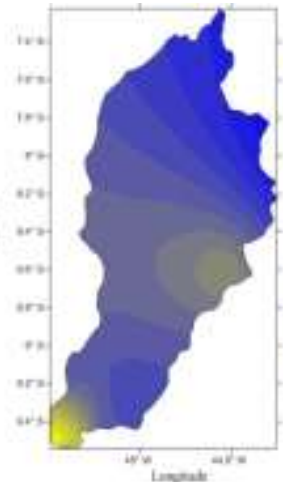

(b)
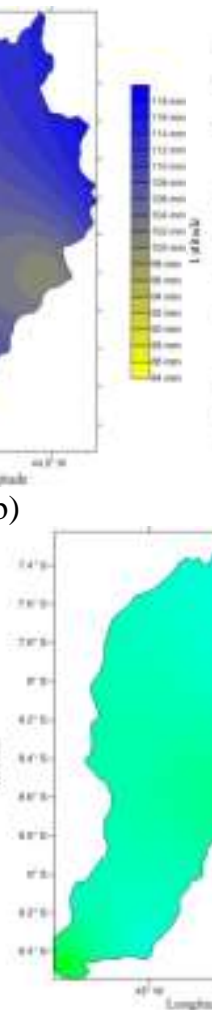

(d)

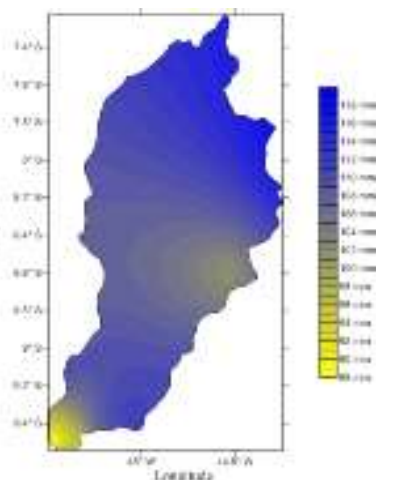

(c)

Source: Adapted from Medeiros (2016). 
In Figure 7 (a, b, c, d, e) represents the variability of evapotranspiration - ETP: (a) minimum; (b) maximum; (c) minimum four months (d) maximum four months; (e) and annual, for the Uruçuí Preto river basin area - PI.

In Figure 7a we have the minimum evapotranspiration rates that occur in February with fluctuation from 84 to 118 $\mathrm{mm}$; the areas with lower ETP rates are located in the extreme south and the eastern part of the central region, while the northern, northeastern, and southeastern sectors have high ETP rates.

In Figure $7 \mathrm{~b}$ shows a south-north increase throughout the BHRUP, with its minimum values of maximum values located in the extreme south and a small strip to the east of the central area.

In Figure 7c is presented as an evaporative behavior of the four-month minimum ETP, where they are located in the extreme south and a band east of the central area; the other areas present values in gradual increases with variability ranging from 98 to $118 \mathrm{~mm}$.

In Figure $7 d$ is evidenced by the variability of evapotranspiration of the four months maximum between August and September; with its variability ranging from 114 to $158 \mathrm{~mm}$, the lowest evapotranspiration rates occur in the extreme south, and in other areas is seen a gradual increase in maximum evapotranspiration.

In Figure 7e shows the lowest annual evapotranspiration rates in the extreme south and the eastern area of the central region, the other areas present evapotranspiration in elevations, and their maximum values occur in the northern, northeastern, and southwestern sectors. Its annual fluctuation occurs in the range of 1,160 to $1,600 \mathrm{~mm}$.

Figure 7. Evapotranspiration (mm): (a) minimum; (b) maximum; (c) minimum four months; (d) maximum four months; (e) and annual.

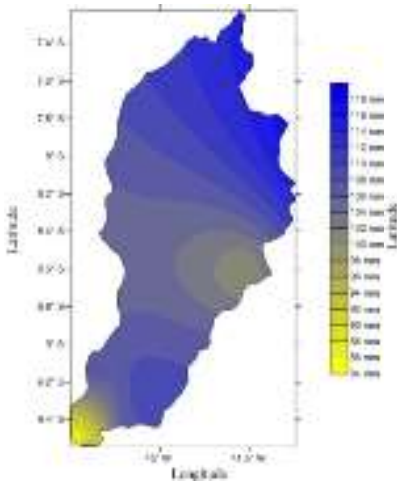

(a)

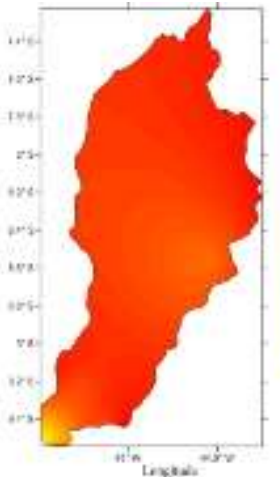

(b)

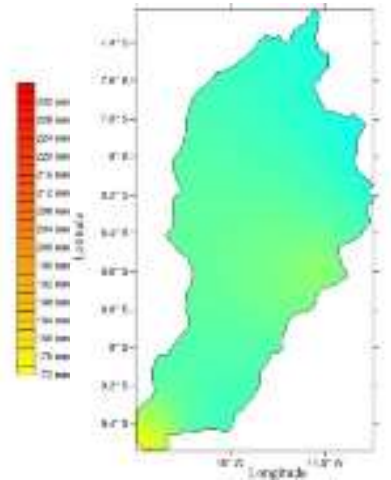

(c)

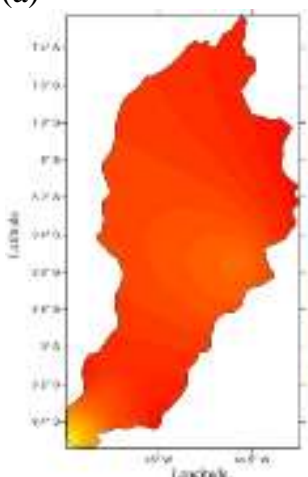

(d)

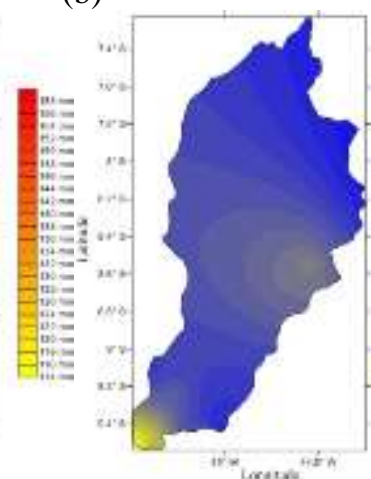

(e)

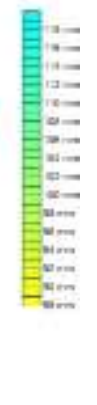

Source: Adapted from Medeiros (2016)

Figures 8 (a, b, c, d, e) represent the variability of total insolation (a) minimum; (b) maximum; (c) four-month minimum; (d) four-month maximum; (e) and annual, for the Uruçuí Preto river basin area - PI. 
In Figure 8a, we observe the minimum total insolation (February) behavior in the BHRUP, where its variability oscillates between 155 to 178 hours, with emphasis on the small area to the southwest with 157 hours of total insolation. In the total maximum insolation (September) (in Figure 8b), we observe areas of maximum insolation in the extreme south and east of the central region, ranges of moderate insolation in the south and central region, an intermediate-range of insolation in the southern and central sectors, and low insolation in an isolated area of the southern region and the north and northeast of the northern region.

Figure 8c shows the total insolation oscillations for the four months with minimum insolation (December, January, February, and March) with an increase in the southeast-north position with a variability of 167 to 181 hours, it stands out a small area in the southwest in the city of Santa Filomena with 157 hours.

In Figure 8d represents the total insolation for the four months of maximum insolation (June, July, August, and September). One can see small areas of low insolation in the southwestern, extreme northern, and northeastern sectors, extreme insolation in the southwestern, western, and eastern sectors of the central area, and a reduction in the southern-northern direction. The variability of the total insolation oscillates from 2520 to 2750 hours within the BHRUP; a reduced area in the southwest of the basin stands out, in which its insolation is the minimum $2520 \mathrm{~h}$, according to Figure $8 \mathrm{e}$.

Figure 8. Total insolation (hours): (a) minimum; (b) maximum; (c) minimum four-month period; (d) maximum four-month period; (e) and annual.

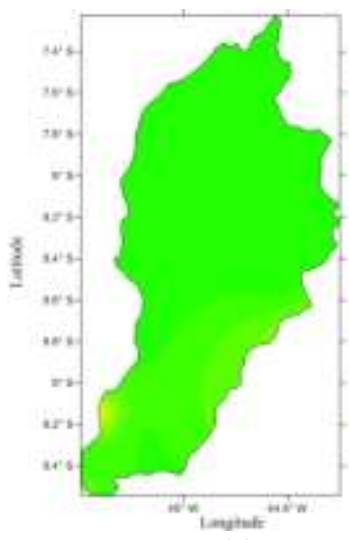

(a)

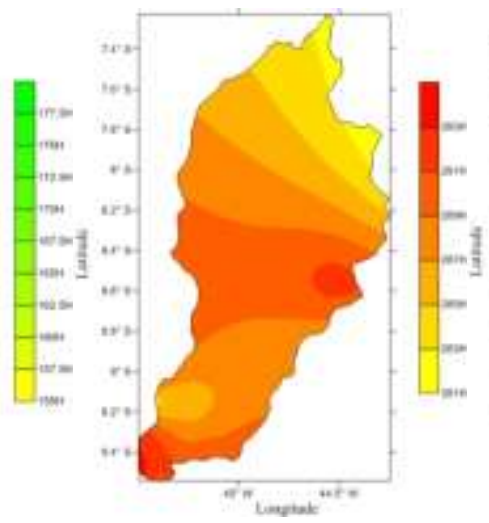

(b)

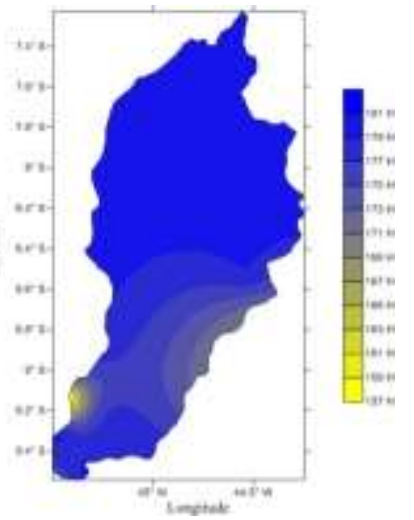

(c)

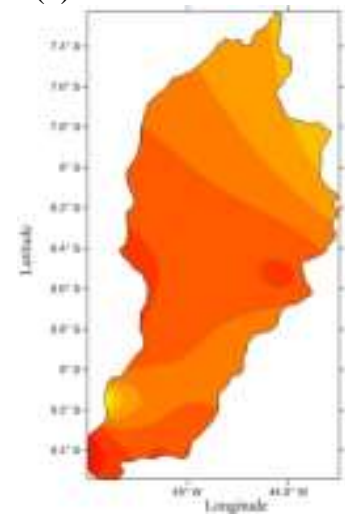

(d)
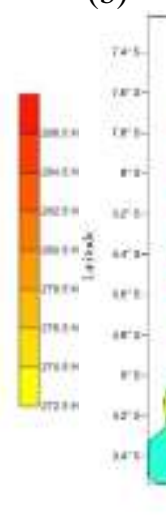

Source: Adapted from Medeiros (2016).

Figures 9 (a, b, c, d, e) represent the variability of cloud cover: (a) minimum; (b) maximum; (c) four-month minimum; (d) four-month maximum; (e) and annual, for the Uruçuí Preto river basin area - PI. 
Figure 9a demonstrates the variability of the minimum cloud cover for the BHRUP, the lowest cloud coverages occur in the southern area of the central sector and northern area of the southern sector, and the eastern sector of the BHRUP, in the southern sector of the southern area and the northern sectors of the central and in almost the entire area of the northern sector the fluctuability of cloud cover oscillates between 2.5 to 2.9 tenths.

In Figure 9b, the variability of maximum cloud cover fluctuates between 6.6 to 7.1 tenths, and its increases occur in the east-northwest direction. Its smallest areas of cloud cover occur in the eastern position and the southern end of the BHRUP. Figure 9c represents the cloud cover in the four months of minimum cloud cover in the area of BHRUP (June to September); it highlights the area of lowest cloud cover located east-northeast; the other areas have a variability of coverage ranging from 6 to 6.9 tenths.

In Figure 9d represents the cloud cover in the four months of maximum cloud cover in the BHRUP area (October to March). We highlight the far south and east areas with low cloud cover and the coastal part of the western region, where there is maximum cloud cover.

In Figure 9e shows the annual variability of cloud cover for the BHRUP; there is a gradual increase in the northeastsouthwest direction, the largest areas with cloud cover are concentrated in the southwestern region and the coastal area of the western region ranging from 4.9 to 5.3 tenths and an area of low cloud cover in the northeastern sector with an oscillation between 4.7 and 4.9 tenths of coverage.

Figure 9. Cloud cover (tenths): (a) minimum; (b) maximum; (c) four-month minimum; (d) four-month maximum; (e) and annual.

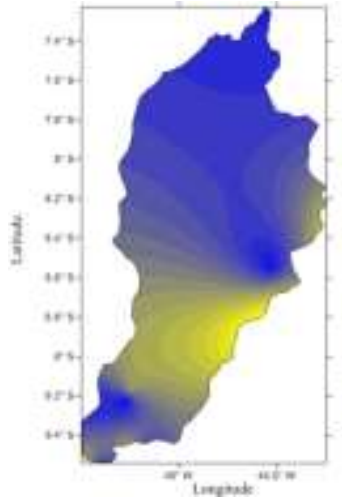

(a)

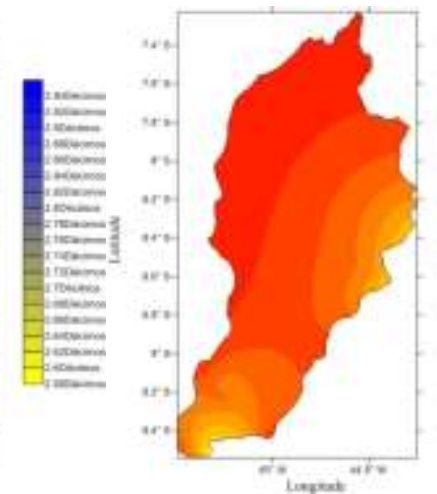

(b)

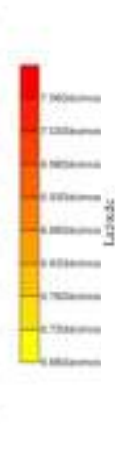

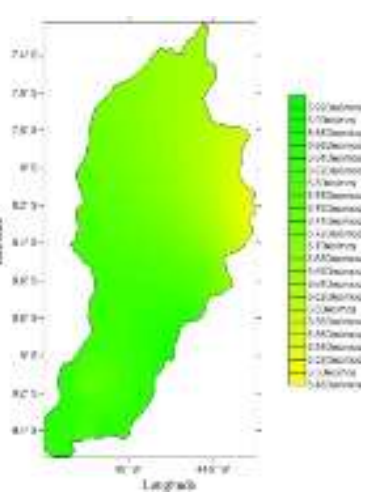

(c)

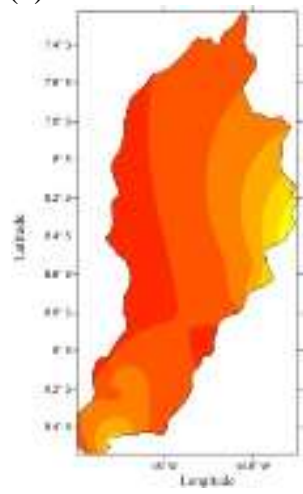

(d) (b)

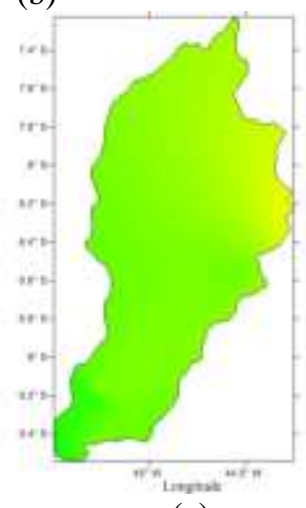

(e)

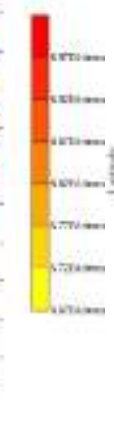

Source: Adapted from Medeiros (2016).

In Figure 10 (a, b, c, d, e) represent the variability of relative humidity (a) minimum; (b) maximum; (c) four-month minimum; (d) four-month maximum; (e) and annual, for the Uruçuí Preto river basin area - PI. 
The variability of the minimum relative humidity (RH) (September) in the BHRUP area is represented in Figure 10a, which oscillates between 47.2 and $52.6 \%$.

In Figure 10b shows the oscillations of maximum RH (February), highlighting the area to the east and the northern sectors of the central region and the southern sector of the northern region, and a small area in the southern sector with low RH concentrations.

In Figure 10c, we observe the fluctuations of RH in the four months of minimum humidity; it appears that in the northern region and northern part of the central region and the extreme south and southwest are concentrated the values of high humidity and in the southeast sector stands out the lowest values of RH for the minimum four-month period.

In Figure 10d has the representation of the four months of maximum RH of the area under study, the central region presents the lowest concentration of RH as well as a small area in the southern sector, in the northern sector of the central area, and throughout the northern sector and in isolated areas of the southern sector there are the highest rates of RH concentration.

In Figure 10e, we have the annual RH fluctuations for the BHRUP area, where its variability flows between 63.3 and $66.2 \%$, observing that the highest RH concentrations occur in the southwestern, southeastern, and northern sectors of the central region and the entire area of the northern sector, while the lowest annual rates occur in the southeastern sector of the central region and the northern part of the southern region.

Figure 10. Relative humidity (\%): (a) minimum; (b) maximum; (c) four-month minimum; (d) four-month maximum; (e) and annual.

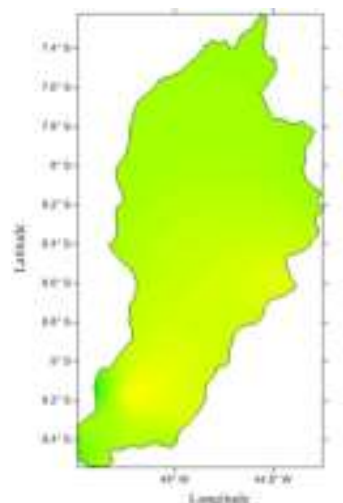

(a)

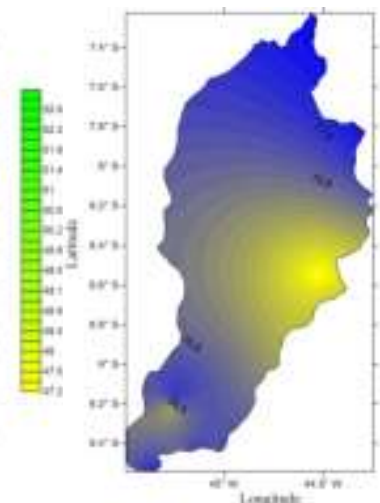

(b)

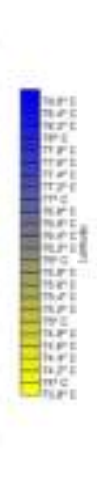

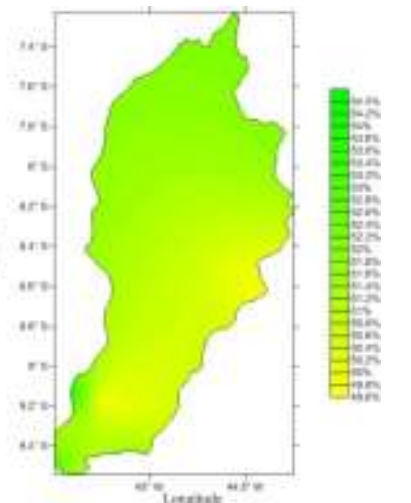

(c)

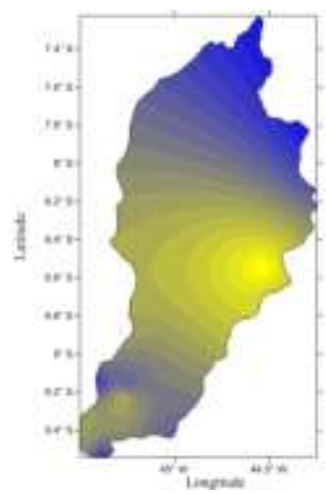

(d)
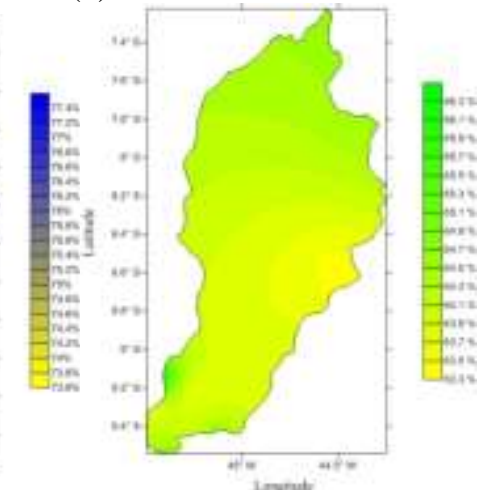

(e)

Source: Adapted from Medeiros (2016).

Figure 11 (a, b, c, d, e) represents the variability of the wind intensity (a) minimum; (b) maximum; (c) four-month minimum; (d) four-month maximum; (e) and annual, for the Uruçuí Preto river basin area - PI. 
Figure 11a represents the minimum wind intensity in the BHRUP, and a reduction of intensity is observed in the eastwest direction and the areas with lower intensities located at the extreme south and west of the figure.

The maximum wind intensities are represented in Figure 11b, where their intensities flow between 1.71 to $1.98 \mathrm{~ms}-1$. Figure 11c has the oscillations of wind intensity for the four months of minimum intensities; it is noteworthy the area in the extreme south as low intensity, in the southern region the high wind intensities are observed and also in the riverine strip of the eastern sector, in other areas, there are moderate intensities.

In Figure 11d, it is observed the predominance of the intensity of the four-month maximum wind in the southwestern sector and the areas of the southern and central regions, in the northern and eastern regions of the central area have the lowest wind intensities representative of the four months.

In Figure 11e represents the annual wind intensity, with the following highlights in the area of small wind intensity in the far south and the central part to the north of the southern region is the highest intensities and moderate winds in the northern sector of the central region and throughout the area of the northern region.]

Figure 11. Wind intensity (MS-1): (a) minimum; (b) maximum; (c) four-month minimum; (d) four-month maximum; (e) and annual.

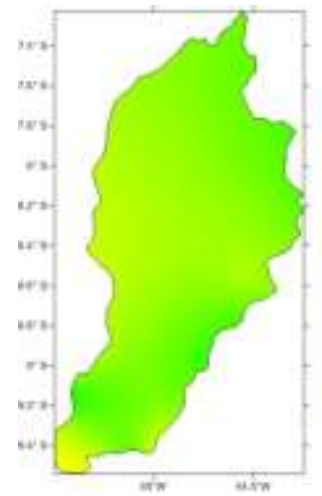

(a)

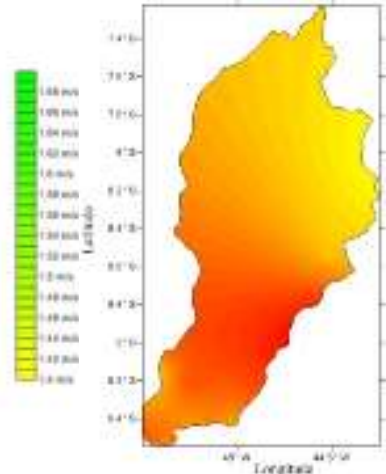

(b)

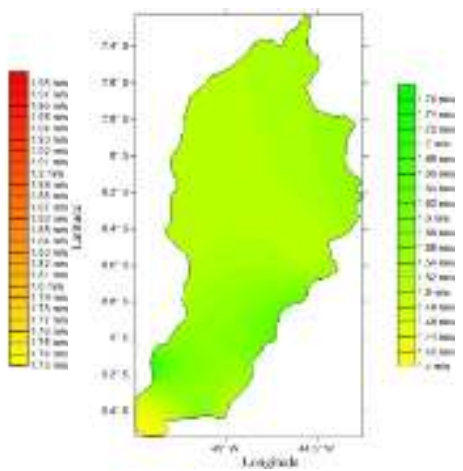

(c)

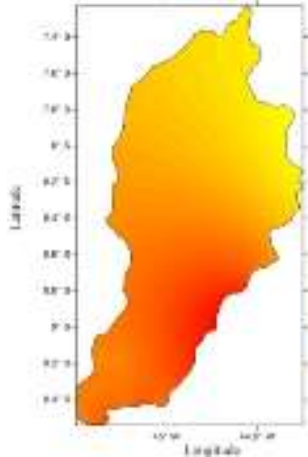

(d)

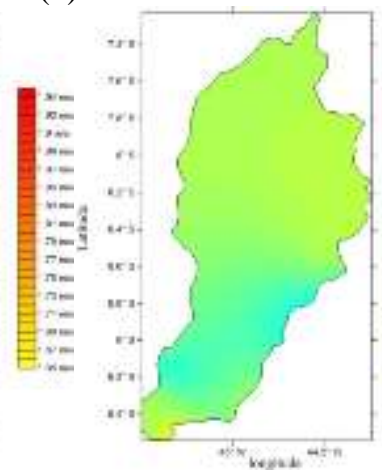

(e)

Source: Adapted from Medeiros (2016).

In Figure 12 (a, b, c, d, e) represents the variability of rainfall (a) maximum; (b) minimum; (c) rainy four months; (d) dry four months; $€$ and annual, for the Uruçuí Preto river basin area - PI.

In Figure 12a highlights the southern area in its center, which recorded the highest rainfall intensities, while in the southwestern and southeastern sectors occurred the lowest rainfall indices, while in the other areas of the basin, the rainfall indices are insignificant for farming and water storage. 
In Figure 12b represents the maximum rainfall occurring in the BHRUP, observing that the rainfall occurs in an eastwest direction and its maximum values occur in the extreme southwest and the coastal area of the basin.

In Figure 12c shows the behavior of the dry four-month period in which the highest rainfall indices are observed in the southern region and its gradual reduction until the northern region where the lowest rainfall indices are observed.

In Figure 12d, it is highlighted that the occurrences of rainfall for the dry four months occur with greater significance in the central part of the basin towards the west, in the eastern sector until the middle of the basin, the lowest rainfall indexes are concentrated, these rains are of low magnitudes and short time interval.

Figure 12e shows the behavior of the annual precipitation distribution in the BHRUP area, which highlighted an increase in the east-west direction, an area of maximum pluviometry is observed in the height of the municipality of Santa Filomena and skirting the west coastal area of the basin. To the east of the basin, there is an area with low rainfall indices, and its fluctuations of increase towards the center of the basin are highlighted.

Figure 12. Precipitation (mm): (a) minimum; (b) maximum; (c) rainy four months; (d) dry four months; $€$ and annual.

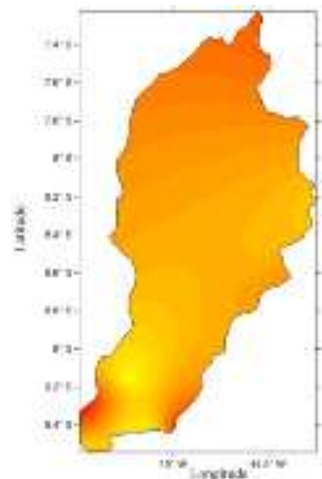

(a)
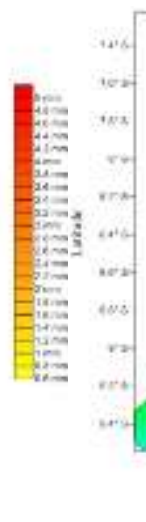

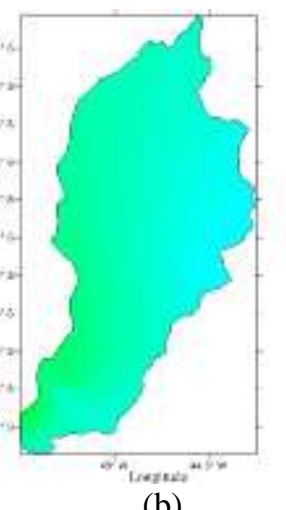

(b)

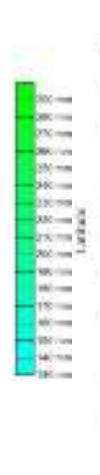

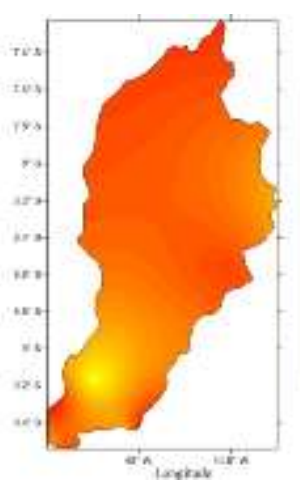

(c)

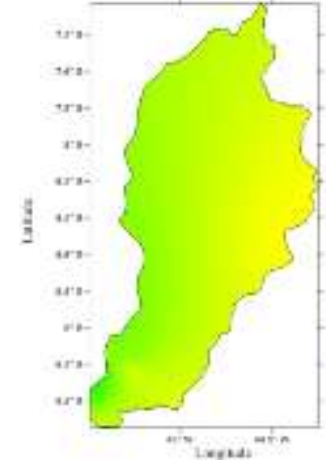

(d) (b)

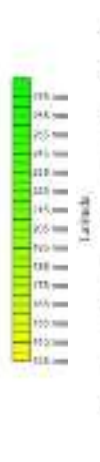

(e)

Source: Adapted from Medeiros (2016)

Relative humidity can be an active or passive contributor to soil degradation and desertification because with other meteorological elements benefiting or disfavoring soil drying and defragmentation, it can contribute to the increase or reduction of fire outbreaks and air quality (Medeiros, de Medeiros \& LIMA, 2011).

In a climate analysis, it is worth considering the periods where the intermittence of rain, even in summer, can present long daily periods without rain. That is because there are irregularities in meteorological systems. As well as the temporal and spatial variability of rainfall, it is a climate attribute in tropical climate regions, as it is understood as a system of relationships between atmospheric attributes, such as wind, temperature, and humidity, with geographic factors such as relief, land use, latitude, continentality, among others, related (Moura \& Jardim, 2017). 


\section{Conclusion}

The results presented indicate possible climatic variations in air temperature, relative humidity, and precipitation, pointing to a trend towards warmer and rainier conditions.

An anomalous effect of precipitation distribution is observed during the January summers. The variability of fluctuations in maximum air temperature increases, the reduction in relative humidity, and the increases in rainfall indices may be related to local changes.

The annual maximum air temperature showed great variation among the studied period, the absolute maximum temperature was increased by $10.8 \%$, and the absolute minimum temperature suffered an increase of $9.5 \%$.

The total annual precipitation showed a gradual increase in its indices since the $1980 \mathrm{~s}$, which may be related to the increase in temperature; it is observed that since the $1990 \mathrm{~s}$, a gradual reduction may be related to the increase in temperature and consequently with greater water evaporation. It can be observed that the relative humidity in the dry months reached critical levels below $15 \%$.

The extreme, maximum and minimum, and average temperature can contribute to desertification and soil degradation because it causes the drying up and defragmentation of the soil and makes the withering point in the vegetation.

The wind directions and speeds are responsible for the transport of dust, smoke, and grain, in addition to causing the drying out of the soil and causing erosion, plant lodging, the spread of pests and diseases; it contributes to a better rate of evaporation and evapotranspiration, increases the intensities of the flames in hotspots and fires, reduces the thermal sensation.

Thus, through the data inferred in this work, we can have subsidies to plan future actions in projects for the recovery of degraded areas and urban development, both as an aid in clean and renewable energy generation projects (wind power, for example), in large agricultural projects, minimizing the chances of occurrence of lodging through wind barriers that can be deployed, in addition to contributing to the planning of cities, industrial parks, and leisure.

The meteorological variables analyzed can be contributing factors to the agricultural sustainability process. Considering consecutive years, in which the extremes seen occur systematically, one can have factors that added together, would induce sustainability, causing problems directly related to flora and consequently the fauna of the place under study.

\section{Acknowledgments}

The Federal Rural University of Pernambuco; the Graduate Program in Biometrics and Applied Statistics at UFRPE; to the Coordination for the Improvement of Higher Education Personnel - CAPES.

\section{References}

Campos, C. G. C. (2010). Padrões climáticos atuais e futuros de temperatura do ar na Região Sul do Brasil e seus impactos nos cultivos de pêssego e de nectarina em Santa Catarina. 191 f. Tese (Doutorado em Meteorologia) - Instituto Nacional de Pesquisas Espaciais, São José dos Campos.

Cavalcanti, E. P., \& Silva, E. D. V. (1994, October). Estimativa da temperatura do ar em função das coordenadas locais. In Congresso Brasileiro de Meteorologia (Vol. 8, No. 1994, pp. 154-157).

Cavalcanti, E. P., Silva, V. D. P., \& de Sousa, F. D. A. (2006). Programa computacional para a estimativa da temperatura do ar para a região Nordeste do Brasil. Revista Brasileira de Engenharia Agrícola e Ambiental, 10, 140-147.

Coe, M. T., Costa, M. H., \& Soares-Filho, B. S. (2009). The influence of historical and potential future deforestation on the stream flow of the Amazon RiverLand surface processes and atmospheric feedbacks. Journal of hydrology, 369(1-2), 165-174.

Comdepi. Companhia de desenvolvimento do Piauí (2002). Estudo de viabilidade para aproveitamento hidroagrícola do vale do rio Uruçuí Preto. Teresina, 2002 .

Costa, MH, Yanagi, SN, Souza, PJ, Ribeiro, A., \& Rocha, EJ. (2007). Mudanças climáticas na Amazônia causadas pela expansão da área de cultivo da soja, em comparação com a expansão das pastagens. Geophysical Research Letters , 34 (7). 
Costa, R. F. D., Feitosa, J. R. P., Fisch, G., Souza, S. S. D., \& Nobre, C. A. (1998). Variabilidade diária da precipitação em regiões de floresta e pastagem na Amazônia. Acta amazônica, 28(4), 395-395.

Costa, T. S. A., Costa Filho, J. F., \& Baracho, D. C. (2011). Análise da temperatura do ar em Areia-PB, em anos de ocorrência de "El Niño". In XVII Congresso Brasileiro de Agrometeorologia - 18 a 21 de Julho de 2011 - SESC. Centro de Turismo de Guarapari, Guarapari - ES

D'Almeida, C., Vörösmarty, CJ, Marengo, JA, Hurtt, GC, Dingman, SL, \& Keim, BD (2006). Um modelo de balanço hídrico para estudar a resposta hidrológica a diferentes cenários de desmatamento na Amazônia. Journal of Hydrology , 331 (1-2), 125-136.

Diaz, C. C. F., Pereira, I. M., \& Soares, D. B. (2017). Relações entre a variabilidade pluviométrica e a produtividade agrícola do algodão herbáceo no Semiárido brasileiro. Os Desafios da Geografia Física na Fronteira do Conhecimento, 1, 2115-2126.

Emater-PI. (2021). Empresa de Assistência Técnica e Extensão Rural do Estado do Piauí. http://www.emater.pi.gov.br/index.php

Eguchi, B., \& Albino, J. (2021). Influência dos Modos de Variabilidade Climática Sobre Eventos De Ressacas No Litoral Sul Do Espírito Santo, Brasil. Revista Brasileira de Climatologia, 28.

Fernando, C. A. (2008). Análise de Discurso: Reflexões Introdutórias. 2a ed. São Carlos: Claraluz.

Galvani, E., Klosowski, E. S., Cunha, A. D., \& Martins, D. (1999). Caracterização da direção predominante do vento em Maringá, PR. Revista Brasileira de Agrometeorologia, Santa Maria, 7(1), 81-90.

Lima, R. A. F. A., Menezes, H. E. A., \& De Brito, J. I. B. (2010). Diagnóstico de tendência de mudanças na temperatura do ar no nordeste setentrional. Revista Caatinga, 23(2), 117-124.

Maluf, R. S.; Rosa, T. S. (2011). Mudanças climáticas desigualdade sociais e populações vulneráveis no Brasil. Construindo capacidade: Relatório Técnico, (2), p.307.

Marengo, J. A., \& Camargo, C. G. (2007). Trends in Extreme air temperatures in Southern Brazil. International Journal Climatology, 28, 893-904.

Medeiros, R. M., Cavalcanti, E. P., \& Medeiros Duarte, J. F. (2020). Classificação climática de köppen para o estado do Piauí-BrasiL. Revista Equador, 9(3), 82-99.

Marinho, R. R., \& Rivera, I. A. (2021). A Precipitação Estimada por satélite na Bacia Do Rio Negro, Noroeste Amazônico (1981-2017). Raega-O Espaço Geográfico em Análise, 50, 44-61.

Medeiros, R. M..; De Medeiros, A. M. T. \& LIMA, R. C. C. (2011). Estudo dos elementos meteorológicos do município de gilbués - pi, uma contribuição para o desenvolvimento sustentável nas áreas críticas à desertificação e a seca. In XVII Congresso Brasileiro de Agrometeorologia - 18 a 21. http://www.sbagro.org/files/biblioteca/3794.pdf

Medeiros, R. D., Sousa, F. D. A. S., Gomes Filho, M. F., \& Francisco, P. R. M. (2014). Variabilidade da umidade relativa do ar e da temperatura máxima na bacia hidrográfica do rio Uruçuí Preto. Educação Agrícola Superior,(28), 136-141.

Medeiros, R. M. (2013). Estudo agrometeorológico para o Estado do Piauí. 119p. Reedição. Divulgação Avulsa.

Medeiros, R. M. (2016). Análise de aspectos climático, socioeconômico e ambiental e seus efeitos na bacia hidrográfica do rio Uruçuí Preto e entorno. Tese de doutorado em meteorologia da Universidade Federal de Campina Grande, do programa de pós-graduação em meteorologia. http://dspace.sti.ufcg.edu.br:8080/jspui/handle/riufcg/1440

Medeiros, R. M., de Holanda, R. M., \& Alexandre, M. (2018). Climate classification in Köppen model for the state of Pernambuco-Brazil. Revista de Geografia (Recife), 35(3)

Medeiros, R. M., Santos, D. C., Sousa, F. A. S., \& Gomes Filho, M. F. (2013). Análise climatológica, classificação climática e variabilidade do balanço hídrico climatológico na bacia do Rio Uruçui Preto, PI. Revista Brasileira de Geografia Física, 6(4), 652-664.

Medeiros, R. M.; Dal Poggetto L. R; e Rocha, F. C. (2010). Estudo da direção predominante do vento na Lagoa do Portinho localidade entre os municípios de Luis Correia e Parnaíba - Piauí, no período de dezembro de 2008 a fevereiro de 2010. In Exposição em postes em feiras de ciências dos colégios de Teresina e na sexta-feira culturais do Centro de Educação Ambiental da SEMAR-PI.

Moura, F. P., \& Jardim, C. H. (2017). Variação temporal das chuvas em Januária, Carinhanha e Montes Claros, norte do estado de Minas Gerais. Os Desafios da Geografia Física na Fronteira do Conhecimento, 1, 2705-2709.

Ortolani, A. A., \& Camargo, M. D. (1987). Influência dos fatores climáticos na produção. Ecofisiologia da produção agrícola. Piracicaba: Potafos, 249.

Paula, R. D., Brito, J. D., \& Braga, C. C. (2010). Utilização da análise de componentes principais para verificação da variabilidade de chuvas em Pernambuco. In XVI Congresso Brasileiro de Meteorologia. Anais... Belém do Pará, PA.

Rodrigues, J. D. O., Partelli, F. L., Pires, F. R., Oliosi, G., Espindula, M. C., \& Monte, J. A. (2016). Volatilização de amônia de ureias protegidas na cultura do cafeeiro conilon. Coffee Science, Lavras, 11(4), 530 - 537.

Rusticucci, M., \& Barrucand, M. (2004). Observed trends and changes in temperature extremes over Argentina. Journal of Climate, 17(20), 4099-4107.

Sampaio, G., Nobre, C., Costa, M. H., Satyamurty, P., Soares-Filho, B. S., \& Cardoso, M. (2007). Regional climate change over eastern Amazonia caused by pasture and soybean cropland expansion. Geophysical Research Letters, 34(17). 
Research, Society and Development, v. 10, n. 11, e554101120055, 2021

(CC BY 4.0) | ISSN 2525-3409 | DOI: http://dx.doi.org/10.33448/rsd-v10i11.20055

Santana, M. O., Sediyama, G. C., Ribeiro, A., \& Silva, D. D. (2007). Caracterização da estação chuvosa para o estado de Minas Gerais. Revista Brasileira de Agrometeorologia, 15(1), 114-120.

Silva, V. D. P. R. (2004). On climate variability in Northeast of Brazil. Journal of Arid Environments, 58(4), 575-596.

Silva, V. M. A.; Medeiros, R. M.; Santos, D. C. \& Gomes Filho, M. F. (2013). Variabilidade pluviométrica entre regimes diferenciados de precipitação no Estado do Piauí. Revista Brasileira de Geografia Física. Recife - PE, 1463 - 1475.

Soriano, B. M. A. (1997). Caracterização climática de Corumbá-MS. Embrapa Pantanal-Boletim de Pesquisa e Desenvolvimento (INFOTECA-E).

Sousa Silva, I. A., \& Suertegaray, D. M. A. (2018). Arenização no Brasil:: Um Comparativo com as Variações Climáticas Regionais. Revista De Geografia$P P G E O-U F J F, 8(2), 01-11$.

Sudene. (1990). Dados pluviométricos mensais do Nordeste: estado do Piauí. Recife. 